\title{
Height estimation from head dimensions in South-South Nigeria
}

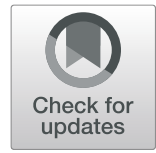

\author{
Dennis E. O. Eboh ${ }^{1 *}$ (D) and John O. Ohaju-Obodo ${ }^{2}$
}

\begin{abstract}
Background: Height estimation is an important stage of forensic investigation to identify an unknown person. The problem of unidentified human remains in the study area, due to local militia activities, kidnapping, and murder, necessitated this study to assess the correlation between the body height and head dimensions and to formulate regression models for estimation of height that are population and gender-specific.
\end{abstract}

Materials and methods: The study involved 952 subjects (464 males and 488 females), aged 18-30 years, from five ethnic groups and sampled from six universities in South-South Nigeria. Stature, head circumference, head length, and head width were measured using a standard anthropometric method. The data collected were analyzed using IBM SPSS Statistics 20. Statistical significance was pegged at $p<0.05$.

Results: There was a significantly greater head dimension in males compared to females. There was a significant relationship between height and head dimensions in the majority of data. The relationship of the head circumference with stature was strongest in male data among the Bekwara and combined data among the Esan and Urhobo. Regarding the head length, the strongest relationship was in females and combined data among Bekwara, and males and combined data among the Ogbia had the strongest relationship. The relationship of stature with the head width was strongest in males and combined data among the Bekwara, and female data among the Ogbia.

Conclusion: This study showed that head dimensions can be used as tools in the height reconstruction of an individual using simple and multiple regression models, and this has medico-legal implication.

Keywords: Forensic anthropology, Head dimension, Height estimation, Regression analysis, Nigeria

\section{Background}

Legal issues, such as mass disaster situation-plane crashes, traffic accidents, genocide, natural disasters, or when unknown bodies are recovered, the services of forensic anthropologists may be required for individual identification (Zeybek et al. 2008). Estimating height or stature is one of the key elements in the human identification process. A definite biological relationship exists between the body height and all parts of the body (Kamal and Yadav 2016), including the head, bodies, and trunks.

The natives of the South-South zone of Nigeria have been raising the alarm concerning the environmental pollution caused by oil exploration and neglect of this

\footnotetext{
*Correspondence: deeboh@delsu.edu.ng; drebohdennis@gmail.com ${ }^{1}$ Department of Human Anatomy and Cell Biology, Faculty of Basic Medical Sciences, College of Health Sciences, Delta State University, P.M.B. 1, Abraka, Nigeria
}

Full list of author information is available at the end of the article area. This has bred restiveness, local militia activities, kidnapping, and murder, with attendant isolated or the whole human body (Nkejiaka 2010). This is of medicolegal importance and within the purview of forensic anthropology.

One of the reasons why scientists use the bones in human identification is that they are durable after death, even when the soft tissues have decomposed, withstanding taphonomic degradation. In particular, the skull is used in identification because it contains hard and durable parts such as the mastoid bone and can remain intact for a long time (Buran et al. 2018; Kanchan et al. 2013).

Various studies have been conducted on height estimation from head dimensions in adults in different populations across the world. In a study conducted in Nigeria (Eboh and Igbigbi 2017), correlation of height with head circumference and length in most of the data was significant and positive. In the same study, the 
correlation of the height with head width was not significant in the majority of the data studied. Another study (Jervas et al. 2015) noted a significant positive correlation between the height and head width. In addition, another study conducted in Nigeria (Ukoha et al. 2015) showed that the relationship of the height with head circumference and the length was significant and positive, but the relationship with the head width in males was not significant. In a study in India (Marko et al. 2018), a significant correlation between the height and head breadth was reported. Also, in another study (Nemade et al. 2015), the correlation of head circumference, length, and width with body height was found to be significant and positive. A significant positive correlation of stature with the head length and width (Agarwal et al. 2014), head length (Chourasia et al. 2014), and head circumference (Mansur et al. 2014) have also been reported. Also, a significant correlation was found between the height and head dimensions (head circumference, length, and width) in another study (Kumar and Gopichand 2013; Singh 2013). A significant positive correlation of height with head circumference, the length and width were also reported in the Indo-Mauritian population (Agnihotri et al. 2011). In Sri Lanka, a correlation of height with cranial length and width was significant and positive (Ilayperuma 2010).

The literature review revealed that studies with the focus of building height from the head or cranial measures using regression methods for the Bekware, Esan, Kalabari, Ogbia, and Urhobo are lacking. The relative gap in the literature is a cause for worries as it may be a hitch in the human identification process. Indigenous forensic tools for determination of height is therefore urgently needed. The study, therefore, will provide relevant guiding tools for forensic anthropologists in the event of medico-legal eventualities. The purpose of this study was to provide population and gender-based regression models for height $(\mathrm{H})$ estimation from the head circumference $(\mathrm{C})$, length $(\mathrm{L})$, and width $(\mathrm{W})$ in young adults.

\section{Materials and methods}

This was a descriptive anthropometric study of the quantitative design. The study population was all undergraduates 18 to 30 years old, who belonged to the Bekware, Esan, Kalabari, Ogbia, and Urhobo ethnic groups in six South-South Nigerian Universities, and who were registered with their ethnic associations in the study centers.

The sample for this study was 952 (464 males and 488 females). Six evenly spread universities were sampled through simple balloting, while the five ethnic groups were selected from the sample frame of ethnic groups in the area. The subjects were stratified into the ethnic groups as well as males and females. At the respective universities, the systematic random sampling technique, which is based on intervals in a numbered population, was finally used to select the subjects.

\section{Subject selection}

Subjects were included in the study if their parents were native of that particular ethnic group for up to two generations. All subjects who had surgery of the head, cranio-facial disorders, or disease (endocrinology and so forth) were excluded.

\section{Ethical consideration}

Informed consent was obtained from subjects in accordance with the World Medical Association Declaration of Helsinki (2013). The Research Ethics Committee of the College of Health Sciences also approved the research protocol.

\section{Method of measurements}

All measurements were in accordance with Eboh and Igbigbi (2017). The head circumference was measured round the head in centimeter as the fronto-occipital circumference at maximum dimension, using non-elastic tailor tape. The head length was measured in centimeter as the linear distance between the glabella and the opisthocranion, using the spreading caliper (ORION, Japan). The head width was also measured in centimeters as the biparietal diameter at the most lateral points, also with the spreading caliper. Standing height or stature was measured in centimeters using the anthropometric rod, as the linear distance from the vertex to the sole of the foot, with the subject standing upright without footwear.

\section{Data analysis}

IBM SPSS Statistics 20 was used to analyze the data collected. Descriptive statistics and $t$ test (to compare the mean between genders) were done. In addition, simple linear regression (of height to the head circumference, length, and width) and multiple regression (of height on all three head dimensions) were also done. Statistical significance was chosen to be at $p<0.05$.

\section{Results}

Results showed the increasing order of contribution of participating ethnic groups to the sample size as follows: Ogbia (86 males, 82 females), Kalabari (89 males, $91 \mathrm{fe}$ males), Bekwara (92 males, 94 females), Esan (92 males, 107 females), and Urhobo (105 males, 114 females).

The comparison of all measured parameters in both genders in all the ethnic groups is shown in Table 1. In the Bekwara and Esan ethnic groups, the mean body height, head circumference, length, and width were significantly greater than females. In the case of Kalabari, 
Table 1 Comparison of measured parameters between males and females in the five ethnic groups

\begin{tabular}{|c|c|c|c|c|c|c|c|c|}
\hline Ethnicity & Measure $(\mathrm{cm})$ & Group & Minimum & Maximum & Mean & $\mathrm{SD}^{\mathrm{a}}$ & $t$ value & $p$ value \\
\hline \multirow[t]{12}{*}{ Bekwara $(N=186 ; M=92, F=94)$} & \multirow[t]{3}{*}{ Height } & Combined & 145.00 & 178.00 & 164.10 & 7.08 & - & - \\
\hline & & Male & 149.00 & 178.00 & 166.54 & 7.16 & 4.940 & 0.001 \\
\hline & & Female & 145.00 & 173.00 & 161.71 & 6.15 & & \\
\hline & \multirow[t]{3}{*}{ Head circumference } & Combined & 49.80 & 58.00 & 54.40 & 1.74 & - & - \\
\hline & & Male & 52.00 & 58.00 & 54.97 & 1.69 & 4.657 & 0.001 \\
\hline & & Female & 49.80 & 56.70 & 53.85 & 1.60 & & \\
\hline & \multirow[t]{3}{*}{ Head length } & Combined & 16.40 & 19.60 & 18.31 & 0.76 & - & - \\
\hline & & Male & 16.80 & 19.60 & 18.61 & 0.72 & 5.678 & 0.001 \\
\hline & & Female & 16.40 & 19.00 & 18.02 & 0.68 & & \\
\hline & \multirow[t]{3}{*}{ Head width } & Combined & 13.20 & 16.60 & 14.90 & 0.77 & - & - \\
\hline & & Male & 13.20 & 16.60 & 15.06 & 0.74 & 2.732 & 0.001 \\
\hline & & Female & 13.30 & 16.60 & 14.75 & 0.77 & & \\
\hline \multirow[t]{12}{*}{$\operatorname{Esan}(N=199 ; M=92, F=107)$} & \multirow[t]{3}{*}{ Height } & Combined & 151.30 & 189.00 & 166.51 & 8.30 & - & - \\
\hline & & Male & 157.00 & 189.00 & 172.15 & 7.35 & 11.462 & 0.001 \\
\hline & & Female & 151.30 & 177.40 & 161.67 & 5.56 & & \\
\hline & \multirow[t]{3}{*}{ Head circumference } & Combined & 49.50 & 59.70 & 54.45 & 2.13 & & \\
\hline & & Male & 51.20 & 59.70 & 55.56 & 1.95 & 7.719 & 0.001 \\
\hline & & Female & 49.50 & 57.50 & 53.50 & 1.81 & & \\
\hline & \multirow[t]{3}{*}{ Head length } & Combined & 16.00 & 20.80 & 18.43 & 0.90 & - & - \\
\hline & & Male & 16.00 & 20.80 & 18.77 & 0.91 & 5.657 & 0.001 \\
\hline & & Female & 16.10 & 19.70 & 18.12 & 0.77 & & \\
\hline & \multirow[t]{3}{*}{ Head width } & Combined & 13.00 & 18.90 & 14.54 & 0.90 & - & - \\
\hline & & Male & 13.20 & 18.90 & 14.94 & 1.06 & 6.316 & 0.001 \\
\hline & & Female & 13.00 & 15.60 & 14.20 & 0.54 & & \\
\hline \multirow[t]{12}{*}{ Kalabari $(N=180 ; \mathrm{M}=89, \mathrm{~F}=91)$} & \multirow[t]{3}{*}{ Height } & Combined & 151.40 & 188.00 & 167.22 & 6.81 & - & - \\
\hline & & Male & 156.00 & 188.00 & 171.17 & 6.20 & 9.353 & 0.001 \\
\hline & & Female & 151.40 & 174.50 & 163.36 & 4.93 & & \\
\hline & \multirow[t]{3}{*}{ Head circumference } & Combined & 43.60 & 64.58 & 54.82 & 2.09 & - & - \\
\hline & & Male & 52.50 & 59.90 & 55.52 & 1.46 & 4.700 & 0.001 \\
\hline & & Female & 43.60 & 64.58 & 54.13 & 2.37 & & \\
\hline & \multirow[t]{3}{*}{ Head length } & Combined & 16.80 & 20.60 & 18.77 & 0.68 & & \\
\hline & & Male & 17.00 & 20.60 & 19.01 & 0.65 & 4.867 & 0.001 \\
\hline & & Female & 16.80 & 19.80 & 18.54 & 0.64 & & \\
\hline & \multirow[t]{3}{*}{ Head width } & Combined & 13.10 & 18.50 & 14.79 & 0.64 & & \\
\hline & & Male & 13.10 & 18.50 & 14.87 & 0.74 & 1.826 & 0.069 \\
\hline & & Female & 13.60 & 15.60 & 14.70 & 0.52 & & \\
\hline \multirow[t]{8}{*}{ Ogbia $(N=168 ; M=86, F=82)$} & \multirow[t]{3}{*}{ Height } & Combined & 160.00 & 178.00 & 167.47 & 5.32 & - & - \\
\hline & & Male & 160.00 & 178.00 & 169.93 & 4.86 & 6.941 & 0.001 \\
\hline & & Female & 160.00 & 175.00 & 164.89 & 4.52 & & \\
\hline & \multirow[t]{3}{*}{ Head circumference } & Combined & 50.93 & 64.58 & 55.15 & 2.23 & - & - \\
\hline & & Male & 52.93 & 57.08 & 55.72 & 1.06 & 3.506 & 0.001 \\
\hline & & Female & 50.93 & 64.58 & 54.55 & 2.89 & & \\
\hline & \multirow[t]{2}{*}{ Head length } & Combined & 17.43 & 19.98 & 18.70 & 0.71 & - & - \\
\hline & & Male & 17.43 & 19.98 & 19.00 & 0.67 & 6.183 & 0.001 \\
\hline
\end{tabular}


Table 1 Comparison of measured parameters between males and females in the five ethnic groups (Continued)

\begin{tabular}{|c|c|c|c|c|c|c|c|c|}
\hline Ethnicity & Measure (cm) & Group & Minimum & Maximum & Mean & $S D^{a}$ & $t$ value & $p$ value \\
\hline & & Female & 17.43 & 19.48 & 18.39 & 0.61 & & \\
\hline & Head width & Combined & 13.93 & 16.08 & 14.99 & 0.48 & - & - \\
\hline & & Male & 14.43 & 16.08 & 15.20 & 0.37 & 6.344 & 0.001 \\
\hline & & Female & 13.93 & 15.58 & 14.78 & 0.49 & & \\
\hline \multirow[t]{12}{*}{ Urhobo $(N=219 ; M=105, F=114)$} & Height & Combined & 150.00 & 183.00 & 166.67 & 8.48 & - & - \\
\hline & & Male & 151.00 & 183.00 & 172.28 & 7.41 & 12.129 & 0.001 \\
\hline & & Female & 150.00 & 178.20 & 161.51 & 5.67 & & \\
\hline & Head circumference & Combined & 43.60 & 60.50 & 54.29 & 2.36 & - & - \\
\hline & & Male & 52.10 & 60.50 & 55.81 & 1.76 & 11.675 & 0.001 \\
\hline & & Female & 43.60 & 57.70 & 52.88 & 1.94 & & \\
\hline & Head length & Combined & 16.60 & 20.50 & 18.50 & 0.79 & - & - \\
\hline & & Male & 17.60 & 20.50 & 18.92 & 0.69 & 8.711 & 0.001 \\
\hline & & Female & 16.60 & 19.50 & 18.11 & 0.68 & & \\
\hline & Head width & Combined & 13.20 & 16.50 & 14.70 & 0.69 & - & - \\
\hline & & Male & 13.20 & 16.50 & 15.094 & 0.65 & 9.563 & 0.001 \\
\hline & & Female & 13.30 & 15.30 & 14.34 & 0.50 & & \\
\hline
\end{tabular}

all parameters measured were also significantly greater in males than females except the head width in which the difference between males and females was not statistically significant. The mean dimensions of the body height and all head parameters measured among subjects of Ogbia and Urhobo ethnic groups were also greater in males than females, and the differences were statistically significant.

Table 2 showed the results of regression analysis between the body height and head circumference in the five ethnic groups. Correlations (R) were statistically significant in the entire ethnic group except for female data among the Esan and Urhobo. The strongest relationship $(R \geq 0.50)$ was observed in male data among the Bekwara, combined data among the Esan and Urhobo. Regression equations for height estimation based on the head circumference are shown in Table 3.

There was a significant correlation between stature and head length, except male data among the Esan and Kalabari, and female data among the Urhobo (Table 4). Female and combined data among the Bekwara and male and combined data among the Ogbia recorded the strongest relationship $(R \geq 0.50)$. The result of the regression analysis of body height with the head length in the five ethnic groups is also shown in Table 4. The highest value of $R^{2}$ was found in Bekwara (female and combined data) and Ogbia (male and combined data). Table 5 showed regression equations for height estimation with the head length in all the ethnic groups.

There was a significant positive correlation between the head width and stature in all the data, except male data among the Esan and Ogbia; male and female data among the Urhobo (Table 6). Male data among the Bekwara recorded the highest correlation $(\approx 0.30)$. Male and combined data among the Bekwara and female data among the Ogbia had the highest value of correlation and $R^{2}$. Table 7 showed regression equations for the estimation of height with head width in all the ethnic groups.

Table 2 Result of simple regression analysis between the height and head circumference in all the ethnic groups

\begin{tabular}{llllllll}
\hline Ethnicity & Group & $R$ & $R^{2}$ & $p$ value & SEE $^{\mathrm{a}}$ & Intercept & Slope \\
\hline Bekwara & Combined & 0.48 & 0.23 & 0.001 & 6.21 & 56.74 & 1.97 \\
& Male & 0.55 & 0.30 & 0.001 & 6.04 & 39.62 & 2.31 \\
& Female & 0.27 & 0.07 & 0.001 & 5.95 & 106.13 & 1.03 \\
Esan & Combined & 0.50 & 0.25 & 0.001 & 7.19 & 60.13 & 1.95 \\
& Male & 0.38 & 0.14 & 0.001 & 6.84 & 92.50 & 1.43 \\
& Female & $0.19^{*}$ & 0.04 & 0.055 & 5.49 & 131.05 & 0.57 \\
Kalabari & Combined & 0.47 & 0.22 & 0.001 & 6.04 & 83.67 & 1.52 \\
& Male & 0.41 & 0.17 & 0.001 & 5.68 & 74.47 & 1.74 \\
& Female & 0.36 & 0.13 & 0.001 & 4.63 & 123.13 & 0.74 \\
Ogbia & Combined & 0.44 & 0.19 & 0.001 & 4.81 & 110.19 & 1.04 \\
& Male & 0.35 & 0.12 & 0.001 & 4.58 & 80.64 & 1.60 \\
& Female & 0.44 & 0.19 & 0.001 & 4.10 & 127.70 & 0.68 \\
Urhobo & Combined & 0.52 & 0.27 & 0.001 & 7.25 & 64.98 & 1.88 \\
& Male & 0.29 & 0.09 & 0.002 & 7.11 & 103.18 & 1.24 \\
& Female & $0.23^{*}$ & 0.02 & 0.176 & 5.65 & 141.82 & 1.24 \\
\hline
\end{tabular}

aStandard error of estimates

*Not significant 
Table 3 Simple regression formulae for height estimation using the head circumference

\begin{tabular}{lll}
\hline Ethnicity & Data & Equation \\
\hline Bekwara & Combined & $H=56.743+1.973 \mathrm{C}$ \\
& Male & $H=39.619+2.309 \mathrm{C}$ \\
& Female & $H=106.126+1.032 \mathrm{C}$ \\
Esan & Combined & $H=60.132+1.954 \mathrm{C}$ \\
& Male & $H=92.498+1.434 \mathrm{C}$ \\
Kalabari & Female & - \\
& Combined & $H=83.670+1.524 \mathrm{C}$ \\
& Male & $H=74.472+1.742 \mathrm{C}$ \\
Ogbia & Female & $H=123.132+0.743 \mathrm{C}$ \\
& Combined & $H=110.194+1.039 \mathrm{C}$ \\
& Male & $H=80.639+1.602 \mathrm{C}$ \\
Urhobo & Female & $H=127.702+0.682 \mathrm{C}$ \\
& Combined & $H=64.98+1.88 \mathrm{C}$ \\
& Male & $H=103.18+1.24 \mathrm{C}$ \\
& Female & - \\
\hline
\end{tabular}

$H$ height, $C$ head circumference

Table 8 showed the multiple regression of body height on head dimensions in the five ethnic groups. In all the data studied, the proportion of the variance in the dependent variable that could be explained by the multiple regression model $\left(R^{2}\right)$ was greater than in the simple regression. Among the Bekwara, the $t$ value corresponding to unstandardized coefficients for the head circumference for combined data and head

Table 4 Result of simple regression analysis between the height and head length in all the ethnic groups

\begin{tabular}{llllllll}
\hline Ethnicity & Group & $R$ & $R^{2}$ & $p$ value & SEE & Intercept & Slope \\
\hline Bekwara & Combined & 0.54 & 0.29 & 0.001 & 5.97 & 71.793 & 5.041 \\
& Male & 0.43 & 0.18 & 0.001 & 6.518 & 76.239 & 4.743 \\
& Female & 0.53 & 0.28 & 0.001 & 5.244 & 87.767 & 4.234 \\
Esan & Combined & 0.41 & 0.17 & 0.001 & 7.59 & 96.535 & 3.798 \\
& Male & $0.16^{*}$ & 0.03 & 0.120 & 7.29 & 147.27 & 1.324 \\
& Female & 0.35 & 0.12 & 0.001 & 5.24 & 115.629 & 2.542 \\
Kalabari & Combined & 0.33 & 0.11 & 0.001 & 6.46 & 106.312 & 3.245 \\
& Male & $0.08^{*}$ & 0.01 & 0.462 & 6.21 & 156.812 & 0.755 \\
& Female & 0.28 & 0.08 & 0.007 & 4.76 & 123.333 & 2.159 \\
Ogbia & Combined & 0.54 & 0.29 & 0.001 & 4.49 & 91.217 & 4.077 \\
& Male & 0.50 & 0.25 & 0.001 & 4.24 & 100.985 & 3.628 \\
& Female & 0.33 & 0.11 & 0.002 & 4.30 & 119.626 & 2.461 \\
Urhobo & Combined & 0.43 & 0.19 & 0.001 & 7.67 & 81.41 & 4.61 \\
& Male & 0.20 & 0.04 & 0.044 & 7.30 & 132.41 & 2.11 \\
& Female & $0.12^{*}$ & 0.01 & 0.203 & 5.66 & 143.28 & 1.01 \\
\hline
\end{tabular}

${ }^{\text {a }}$ Standard error of estimates

*Not significant
Table 5 Simple regression models for height estimation using head length

\begin{tabular}{lll}
\hline Ethnicity & Group & Equation \\
\hline Bekwara & Combined & $H=71.793+5.041 \mathrm{~L}$ \\
& Male & $H=76.239+4.743 \mathrm{~L}$ \\
& Female & $H=87.767+4.234 \mathrm{~L}$ \\
Esan & Combined & $H=96.535+3.798 \mathrm{~L}$ \\
& Male & - \\
Kalabari & Female & $H=115.629+2.542 \mathrm{~L}$ \\
& Combined & $H=106.312+3.245 \mathrm{~L}$ \\
& Male & - \\
Ogbia & Female & $H=123.333+2.159 \mathrm{~L}$ \\
& Combined & $H=91.217+4.077 \mathrm{~L}$ \\
& Male & $H=100.985+3.628 \mathrm{~L}$ \\
Urhobo & Female & $H=119.626+2.461 \mathrm{~L}$ \\
& Combined & $H=81.41+4.61 \mathrm{~L}$ \\
& Male & $H=132.41+2.11 \mathrm{~L}$ \\
\hline $\boldsymbol{H}$ height, $\mathrm{L}$ head length & & - \\
\hline
\end{tabular}

circumference, and length of male, was not significant and did not improve the models. The head length for combined data, head width for male, and head circumference for females were similarly so for the Esan. Among the Kalabari, the head length for combined, male and female data, and head width for the male data also had $t$ values that were not significant. The head circumference and width for males, and the circumference and

Table 6 Result of simple regression analysis between height and head width in all the ethnic groups

\begin{tabular}{|c|c|c|c|c|c|c|c|}
\hline Ethnicity & Group & $R$ & $R^{2}$ & $p$ value & SEE & Intercept & Slope \\
\hline \multirow[t]{3}{*}{ Bekwara } & Combined & 0.54 & 0.29 & 0.001 & 5.97 & 90.160 & 4.961 \\
\hline & Male & 0.56 & 0.31 & 0.001 & 5.98 & 85.258 & 5.398 \\
\hline & Female & 0.47 & 0.22 & 0.001 & 5.45 & 106.665 & 3.731 \\
\hline \multirow[t]{3}{*}{ Esan } & Combined & 0.35 & 0.12 & 0.001 & 7.81 & 120.414 & 3.170 \\
\hline & Male & $0.03^{*}$ & 0.00 & 0.777 & 7.39 & 169.058 & 0.207 \\
\hline & Female & 0.33 & 0.11 & 0.001 & 5.28 & 113.815 & 3.369 \\
\hline \multirow[t]{3}{*}{ Kalabari } & Combined & 0.31 & 0.10 & 0.001 & 6.49 & 118.586 & 3.289 \\
\hline & Male & 0.23 & 0.05 & 0.034 & 6.07 & 143.242 & 1.877 \\
\hline & Female & 0.40 & 0.16 & 0.001 & 4.55 & 107.732 & 3.784 \\
\hline \multirow[t]{3}{*}{ Ogbia } & Combined & 0.49 & 0.24 & 0.001 & 4.66 & 86.273 & 5.415 \\
\hline & Male & $0.14^{*}$ & 0.02 & 0.191 & 4.84 & 141.175 & 1.891 \\
\hline & Female & 0.54 & 0.29 & 0.001 & 3.83 & 91.338 & 4.977 \\
\hline \multirow[t]{3}{*}{ Urhobo } & Combined & 0.34 & 0.11 & 0.001 & 7.99 & 104.68 & 4.22 \\
\hline & Male & $0.04^{*}$ & 0.00 & 0.658 & 7.44 & 171.79 & 0.10 \\
\hline & Female & $0.05^{*}$ & 0.00 & 0.575 & 5.69 & 164.99 & -0.72 \\
\hline
\end{tabular}

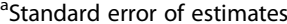

*Not significant 
Table 7 Simple regression formulae for stature estimation using head width

\begin{tabular}{lll}
\hline Ethnicity & Group & Equation \\
\hline Bekwara & Combined & $H=90.160+4.961 \mathrm{~W}$ \\
& Male & $H=85.258+5.398 \mathrm{~W}$ \\
Esan & Female & $H=106.665+3.731 \mathrm{~W}$ \\
& Combined & $H=120.414+3.170 \mathrm{~W}$ \\
& Male & - \\
Combined & Female & $H=113.815+3.369 \mathrm{~W}$ \\
Kalabari & Combined & $H=118.586+3.289 \mathrm{~W}$ \\
& Male & $H=143,242+1.877 \mathrm{~W}$ \\
Ogbia & Female & $H=107.732+3.784 \mathrm{~W}$ \\
& Combined & $H=86.273+5.415 \mathrm{~W}$ \\
& Male & - \\
Urhobo & Female & $H=91.338+4.977 \mathrm{~W}$ \\
& Combined & $H=104.68+4.22 \mathrm{~W}$ \\
& Male & - \\
\hline
\end{tabular}

$H$ height, $C$ head width

length for females of the Esan people also had the $t$ values not significant. Among the Urhobo, the $t$ value corresponding to unstandardized coefficients for the head width in combined data, head length in males, and all the data in females were also not significant. All values that were not significant were excluded from the multiple regression equations for stature estimation (Table 9).

\section{Discussion}

Sexual dimorphism is a usual biological process that occurs in humans with regard to body parts. Height and all head dimensions measured in this study were significantly greater in males compared to females, except for the head width that was not significant among the Kalabari. Concerning height, it is known that males attain puberty 2 years later than their female counterparts, affording them additional time to grow (Eboh and Igbigbi 2017); this could be a reason for the gender difference observed in the present study. Significant greater body height in males compared to females have also been reported in previous studies (Marko et al. 2018; Eboh and Igbigbi 2017; Ukoha et al. 2015; Shah et al. 2015; Agarwal et al. 2014; Mansur et al. 2014; Agnihotri et al. 2011; Ilayperuma 2010; Pelin et al. 2010), which also reported that males are significantly taller than females.

Structurally, the general appearance of the male skull is such that it tends to be larger and heavier or thicker than that of the female which is smaller and lighter (Gleeson 2016). In the present study, the head circumference, length, and width observed to be significantly greater in males than females are to further emphasize and confirm the aforementioned with regard to the five ethnic groups studied.

The differences in the head circumference between males and females observed in all the ethnic groups in the present study are in tandem with previous studies (Marko et al. 2018; Eboh and Igbigbi 2017; Ukoha et al. 2015, Mansur et al. 2014; and Agnihotri et al. 2011). In

Table 8 Result of multiple regression of height on head dimensions

\begin{tabular}{|c|c|c|c|c|c|c|c|}
\hline Ethnicity & Group & $R$ & $R^{2}$ & $p$ value & SEE & Intercept & Slope \\
\hline \multirow[t]{3}{*}{ Bekwara } & Combined & 0.63 & 0.40 & 0.001 & 5.52 & 51.11 & C- $-0.08^{*}$, L3.59**, W 3.46** \\
\hline & Male & 0.63 & 0.39 & 0.001 & 3.69 & 33.61 & C1.31* L0.38*, W3.59** \\
\hline & Female & 0.62 & 0.38 & 0.001 & 4.91 & 87.55 & C-1.03**, L4.86**, W2.84** \\
\hline \multirow[t]{3}{*}{ Esan } & Combined & 0.53 & 0.29 & 0.001 & 7.07 & 48.21 & C1.43**, L1.03*, W1.48** \\
\hline & Male & 0.45 & 0.21 & 0.001 & 6.66 & 91.18 & C2.68** ${ }^{* *}$ L13.03**, W-0.73* \\
\hline & Female & 0.42 & 0.18 & 0.001 & 5.11 & 82.01 & C0.22*, L1.81**, W2.48** \\
\hline \multirow[t]{3}{*}{ Kalabari } & Combined & 0.51 & 0.26 & 0.001 & 5.92 & 55.31 & $\mathrm{C} 1.21^{* *}, \mathrm{~L} 1.20^{*}, \mathrm{~W} 1.57^{* *}$ \\
\hline & Male & 0.43 & 0.19 & 0.001 & 5.69 & 83.07 & C1.83**, L-1.29*,W 0.73* \\
\hline & Female & 0.49 & 0.24 & 0.001 & 4.38 & 79.44 & C0.54**, L0.68* W2.87** \\
\hline \multirow[t]{3}{*}{ Ogbia } & Combined & 0.63 & 0.40 & 0.001 & 4.15 & 48.34 & $\mathrm{C} 0.50^{* *}, \mathrm{~L} 2.51^{* *}, \mathrm{~W} 2.99^{* *}$ \\
\hline & Male & 0.51 & 0.38 & 0.001 & 4.27 & 91.80 & C-0.11*, L3.68**, W0.94* \\
\hline & Female & 0.61 & 0.26 & 0.001 & 3.64 & 75.01 & C0.46**, L0.33*, W3.96** \\
\hline \multirow[t]{3}{*}{ Urhobo } & Combined & 0.55 & 0.30 & 0.001 & 7.16 & 46.39 & C1.41**, L1.78**, W0.74* \\
\hline & Male & 0.35 & 0.12 & 0.004 & 7.04 & 113.92 & C1.43** L0.75* W-2.37** \\
\hline & Female & 0.16 & 0.02 & 0.435 & 5.68 & 129.49 & C0.30* L0.73*, W0.22* \\
\hline
\end{tabular}

$C$ head circumference, $L$ head length, $W$ head width

${ }^{\text {a }}$ Standard error of estimates

*Not significant, **significant 
Table 9 Multiple regression models for height estimation from head dimensions

\begin{tabular}{lll}
\hline Ethnicity & Group & Equation \\
\hline Bekwara & Combined & $H=51.11+3.59 \mathrm{~L}+3.46 \mathrm{~W}$ \\
& Male & $H=33.61+3.59 \mathrm{~W}$ \\
& Female & $H=87.55-1.03 \mathrm{C}+4.86 \mathrm{~L}+2.84 \mathrm{~W}$ \\
Esan & Combined & $H=48.2+1.43 \mathrm{C}+1.48 \mathrm{~W}$ \\
& Male & $H=91.18+2.68 \mathrm{C}-13.03 \mathrm{~L}$ \\
& Female & $H=82.06+1.81 \mathrm{~L}+2.49 \mathrm{~W}$ \\
Kalabari & Combined & $H=55.31+1.21 \mathrm{C}+1.57 \mathrm{~W}$ \\
& Male & $H=83.07+1.83 \mathrm{C}$ \\
& Female & $H=79.44+0.54 \mathrm{C}+2.87 \mathrm{~W}$ \\
Ogbia & Combined & $H=48.34+0.50 \mathrm{C}+2.51 \mathrm{~L}+2.99 \mathrm{~W}$ \\
& Male & $H=91.80+3.68 \mathrm{~L}$ \\
& Female & $H=75.01+0.46 \mathrm{C}+3.96 \mathrm{~W}$ \\
Urhobo & Combined & $H=46.39+1.41 \mathrm{C}+1.78 \mathrm{~L}$ \\
& Male & $H=113.92+1.43 \mathrm{C}-2.37 \mathrm{~W}$ \\
& Female & - \\
\hline
\end{tabular}

$H$ height, $C$ head circumference, $L$ head length, $W$ head width

these studies, they also reported that the head circumference is greater in males than in females. On the other hand, the result of the current study is at variance with Jervas et al. (2015), who reported otherwise. Genetic, environmental, and ethnic factors may be the reasons for the variation.

It was reported in some previous studies (Eboh and Igbigbi 2017; Ukoha et al. 2015; Shah et al. 2015; Agarwal et al. 2014; Ilayperuma 2010) that the head length in males is significantly greater when compared to females; the findings in the present study that males have a longer head than females support the aforementioned. Nevertheless, Jervas et al. (2015) observed no significant difference between males and females in the head length. This discrepancy can be attributed to factors that affect anthropometric measurements.

The significant differences in the head breadth observed between males and females among the Bekwara, Esan, Ogbia, and Urhobo in the present study agree with some previous reports (Jervas et al. 2015; Ukoha et al. 2015; Shah et al. 2015; Agnihotri et al. 2011; Ilayperuma 2010) that reported a significant greater head breadth in males than in females. The aforementioned observation also holds true in four of the five ethnic groups studied in a previous research (Eboh and Igbigbi 2017). On the contrary, among the Kalabari in the present study, there was no significant difference in head breadth between males and females, which is in line with the report on the Annang in a prior study (Eboh and Igbigbi 2017). Population differences may account for variations observed.
The result of the present study indicates in 36 of the 45 cases or data across the five ethnic groups that there was a significant relationship between height and head dimension $(p<0.05)$. The low correlation $(R<0.5)$ between height and head dimensions in 35 of the cases indicates a poor relationship. Agarwal et al. (2014) reported a significant low correlation between the height, and head length and width. Ilayperuma (2010) reported that the correlation between height, and head length and width was significant in both genders.

Marko et al. (2018) observed a significant correlation between height and head circumference. Jervas et al. (2015) observed no significant correlation between height and head circumference. Mansur et al. (2014) noted a significant correlation of stature with the head circumference in both genders and combined data. Ukoha et al. (2015) observed significant correlations between the height, and head circumference, length, and width in both genders, except for the head breadth in which the female data was not significant.

Agnihotri et al. (2011) noted that the head circumference and length showed a significant correlation with height, but the head width showed otherwise. Eboh and Igbigbi (2017) reported that the circumference and head length had a significant positive correlation with the height in all the five ethnic groups studied, except for the male data among the Ukwuani and Bini, in which the correlation of height with the head circumference and head length, respectively, was not significant. In addition, Eboh and Igbigbi (2017) also reported that only combined and female data among the Bini and Ikwere and combined data among the Izon showed a significant positive correlation between the height and head width.

Provided correlation (R) of head dimensions with height was significant, regression equations were formulated (Tables 3, 5, 7, and 9). Results showed in all head dimensions studied, in all the data across the five ethnic groups, that only in male data among the Bekwara, was the proportion of the variance in head circumference and width that could be explained by the model was up to $30 \%$, which is low. Similar results were reported by Eboh and Igbigbi (2017), while Jervas et al. (2015) noted a very low value of $R^{2}$ in female data between the height and head width.

The high error of estimates based on the two regression methods indicates that the level of reliability of the models is low. Variable values of the standard error of estimates have been reported in previous studies (Marko et al. 2018; Eboh and Igbigbi 2017; Ukoha et al. 2015; Krishan 2008; Krishan and Kumar 2007). Genetic, environmental, and nature of the data may be responsible for the variation. 


\section{Conclusion}

In general, across the five ethnic groups studied, there is a significantly greater head dimension in males compared to females. There is a significant relationship between height and head dimensions in the majority of data.

This study envisaged a situation where an isolated head is found, as in a disaster or crime scenarios, the equations derived can be used to estimate the height when the sex of the missing person is still unknown. The models developed are gender- and populationspecific and may not be applied in other populations. The height estimation models are based on a simple regression for partial remains and multiple regression for the complete remains of the head. The findings revealed that these models have the capacity for stature estimation and will be useful in forensic anthropology.

\section{Abbreviations}

C: Head circumference; DEO: Dennis Eboh; F: Female; H: Height or stature; IBM: International Business Machine; JOO: John Ohaju-Obodo; L: Head length; M: Male; N: Number; R: Correlation or regression coefficient; SD: Standard deviation; SEE: Standard error of the estimates; SPSS: Statistica Package for the Social Sciences; W: Head width or breadth

\section{Acknowledgements \\ Many thanks to Prof. PS. Igbigbi, Professor of Physical Anthropology, in the Department of Human Anatomy and Cell Biology, and Prof. JN. Odili, Professor of Educational Administration and Evaluation, in the Department of Guidance and Counseling, Delta State University, for the immense contribution of reviewing the manuscript. \\ Ethical approval and consent to participate \\ Ethical approval was obtained from the Research Ethics Committee of Faculty of Basic Medical Sciences, Delta State University, Abraka, and informed consent was obtained from subjects prior to data collection.}

\section{Authors' contributions}

DEO conceived the idea, perfumed the data collection and statistical analysis, and drafted the manuscript. DEO and JOO took part in the initial experimental design. DEO was supervised by JOO in a Ph. D thesis that formed a part of this study. All authors read and approved the final manuscript.

\section{Availability of data and materials}

The relevant data are within the manuscript.

\section{Consent for publication}

Not applicable.

\section{Competing interests}

The authors declare that they have no competing interests.

\section{Author details}

${ }^{1}$ Department of Human Anatomy and Cell Biology, Faculty of Basic Medical Sciences, College of Health Sciences, Delta State University, P.M.B. 1, Abraka, Nigeria. ${ }^{2}$ Department of Medicine, Faculty of Clinical Sciences, College of Health Sciences, Delta State University, Abraka, Nigeria.

Received: 2 July 2019 Accepted: 11 September 2019

Published online: 04 December 2019

\section{References}

Agarwal S, Agarwal SK, Jain SK (2014) Correlation between the stature and cranial measurements in population of North India. Acta Med Int 1:99-102
Agnihotri AK, Kachhwaha S, Googoolye K, Allock A (2011) Estimation of stature from cephalo-facial dimensions by regression analysis in indo-Mauritian population. J Forensic Legal Med 18:167-172

Buran F, Can IO, Ekizoglu O, Balci A, Guleryuz H (2018) Estimation of age and sex from bimastoid breadth with 3D computed tomography. Rom J Leg Med 26:56-61

Chourasia RS, Bamne A, Shukla SN, Gohiya V, Pandey R (2014) Estimation of stature from head length. Inter J Medical Sci Res Prac 1:40-43

Eboh DEO, Igbigbi PS (2017) Stature estimation from cephalometric parameters of young adults in five Nigerian ethnic groups. Italian J Anat Embryo 122:98-109

Gleeson S (2016) External skull Gray's anatomy. In: Standring S (ed) The anatomical basis of clinical practice, 42st edn. Elsevier, London, United Kingdom

Ilayperuma I (2010) On the prediction of personal stature from cranial dimensions. Int J Morphol 28:1135-1140

Jervas E, Anibeze CIP, Uloneme GC, Anyanwu GE (2015) Stature estimation of the Igbos using cephalo-facial anthropometry. J Forensic Res 6:295

Kamal R, Yadav PK (2016) Estimation of stature from different anthropometric measurements in Kori population of North India. Egypt J Forensic Sci 6:468-477

Kanchan T, Gupta A, Krishan K (2013) Estimation of sex from mastoid triangle - a craniometric analysis. J Forensic Legal Med 20:855-860

Krishan K (2008) Estimation of stature from cephalo-facial anthropometry in north Indian population. Forensic Sci Int 181:52.el-52.e6

Krishan K, Kumar R (2007) Determination of stature from cephalo-facial dimensions in a north Indian population. Leg Med (Tokyo) 9:128-133

Kumar M, Gopichand PW (2013) Estimation of stature from cephalo-facial anthropometry in 800 haryanvi adults. Int J PI An and Env Sci 3:42-46

Mansur DI, Haque MK, Sharma K, Mehta DK, Shakya R (2014) Use of head circumference as a predictor of height of individual. Kathmandu Univ Med J 12:89-92

Marko RS, Awasthi A, Jehan M Estimation of stature from head circumference in population of Malwa region of Central India: a correlational analysis. ParipexIndian Journal of Research 2018; 7(4):44-46

Nemade P, Ambiye M, Nemade A (2015) Regression analysis on stature estimation from cephalic dimensions. Indian J Basic Appl Med Res 4:298-312

Nkejiaka C (2010) Emergency of ethnic movements in the Niger Delta region: from voice to armed struggle in the new democratic era (1999-present). Central European University, Dissertation

Pelin C, Zagyapan R, Yazici C, Kürkcüoglu A (2010) Body height estimation from head and face dimensions: a different method. J Forensic Sci 55:1326-1330

Shah T, Patel M, Nath S, Bhise RS (2015) Estimation of stature from cephalo-facial dimensions by regression analysis in Gujarati population. J Indian Acad Forensic Med 37:253-257

Singh R (2013) Estimation of stature and age from head dimensions in indian population. Int J Morphol 31:1185-1190

Ukoha UU, Umeasalugo KE, Udemezue OO, Asomugha LA (2015) Estimation of stature from cephalic dimensions in a Nigerian population. Rev Arg de Anat Clin 7:17-25

World Medical Association (2013) Declaration of Helsinki: Ethical Principles for Medical Research involving Human Subjects. Retrieved from http://irb.sinica. edu.tw/doc/regulation/declaration\%20of\%20helsinki\%20(2013).pdf

Zeybek G, Ergur I, Demiroglu Z (2008) Stature and gender estimation using foot measurements. Forensic Sci Int. 181:54.e1-5

\section{Publisher's Note}

Springer Nature remains neutral with regard to jurisdictional claims in published maps and institutional affiliations. 